\title{
The Role of International Academic Professionals in the Development of Entrepreneurial Universities in South Africa: Government Funded Universities Perspective
}

\author{
Mary Mutanda, Lawrence Mpele Lekhanya, Sibusiso Moyo \\ Durban University of Technology, South Africa \\ marym@dut.ac.za, lawrencel@dut.ac.za,moyos@dut.ac.za
}

\begin{abstract}
There is a wide belief and acceptance from leading government and business experts that small enterprises and entrepreneurship are the key components to unemployment and poverty alleviation in any country. Unfortunately, high unemployment levels, low entrepreneurial activity and high small business failure rate have become the main characteristics of the South African economy. Post-school education is partially blamed for the dropping levels of entrepreneurial activities in the country. South Africa's tertiary education system continues to focus on producing job-seekers instead of job creators. This problem has forced South African Universities to explore more on their potential of becoming more entrepreneurial, but lack of academics in the field of entrepreneurship has been found to be a hindrance to success in this agenda. To avert this obstacle, it is reiterated that internationalisation is key to any university entrepreneurship strategy, and therefore universities are encouraged to internationalise through attracting international entrepreneurial staff. The purpose of this literature review paper is twofold. The first part explores the role played by international academic professionals in the establishment of entrepreneurial universities in South Africa, while the second aims at evaluating the state of entrepreneurship development in higher education and the potential of South African universities becoming more entrepreneurial. The study employs both quantitative and qualitative research techniques (mixed method). The study reveals that South African universities should internationalise if they are to succeed in the entrepreneurial strategy. In addition, it is found that foreign academics have the required skills and bring in the diverse expertise needed for the establishment of entrepreneurial universities. Moreover, the presence of international academics has enhanced entrepreneurship mindset of local staff and students. It is recommended that universities should establish entrepreneurial institutes which are affiliated to them in order to drive this initiative and that the establishment of entrepreneurial universities is the way to go in South Africa if the country is to beat poverty and unemployment.
\end{abstract}

Keywords: Entrepreneurial University, Entrepreneurship, International academic professionals, Government funded universities

\section{Introduction}

There are a wide belief and acceptance from leading government and business experts that the small enterprises and entrepreneurship is the key to unemployment and poverty reduction (Radipere, 2012). Unfortunately, high unemployment levels, low entrepreneurial activity and high small business failure rate have become the main characteristics of the South African economy (Amadi-Echendu, Phillips, Chodokufa and Visser 2016). Beijnath (2015) partially blames post-school education for the dropping levels of entrepreneurial activities in the country. Beijnath (2015), states that South Africa's tertiary education system continues to focus on producing job-seekers instead of job creators. This problem has forced South African Universities to explore more on their potential of becoming more entrepreneurial for example the University of South Africa is busy trying that (Amadi-Echendu et al., 2016). In as much as universities are willing to succeed in becoming entrepreneurial, they are faced with a lack of academics in the field of entrepreneurship, thereby hindering the entrepreneurial drive in the country (Motsoeneng 2015). There are low numbers of international academics in South African universities when compared to their counterparts elsewhere like the University of Manchester where international academic staff make up 22\% (The University of Manchester 2018). According to the University of Oxford (one of the successful entrepreneurial university) staffing annual report (2017), $40.2 \%$ of their academic staff is made up of non-British academics or international academics (foreign academics) and Coventry University (2018) asserts the same notion of the need to internationalise in order to achieve the best results for the students and university as a whole. To avert this hindrance, Ramjugernath (2015) reiterates that internationalisation is the key to any university entrepreneurship strategy and therefore universities are encouraged to internationalise through attracting international and entrepreneurial staff. Eke, Okoye and Evbuomwan (2018), note that quality education is the 
main remedy to combating dire poverty in developing nations as it is the only way of attaining quality human capital.

They added that developed economies such as the United States of America; Britain, Japan etc. succeeded through the employment quality human capital at both micro and macro levels in their economies. Therefore, the significance of this study is to establish the role played by foreign academic professionals in the development of Entrepreneurial Universities in South Africa and develop an entrepreneurial university establishment model that can be incorporated into South African university education. The model will assist and enhance the training of job creators (entrepreneurship education) instead of job seekers. In addition, the importance of this research is to find the best ways of promoting entrepreneurial universities, one of which being the engagement of foreign academic professional in the South African universities. The study intends to establish the best method that can be used to transfer entrepreneurial knowledge more effectively for the benefit of the broader society. In addition, the literature for this study reviewed so far highlights the need for South African universities to lead entrepreneurship education through the establishment of entrepreneurial universities.

Entrepreneurial universities can only be established and sustained if there are expert academics in the field of entrepreneurship. Since South Africa has a serious shortage of such academics, as reiterated by Motsoeneng (2015:1), it is hoped that the results of this study will contribute towards enlightening government and interested stakeholders about the role of foreign academics in the establishment and sustainability of entrepreneurial universities thereby leading them to revisit their policies on reception and treatment and employment of foreign professionals. It is to determine the extent of the role played by foreign academic professionals in the establishment of entrepreneurial universities in South Africa. This study will provide an understanding of how South African universities should improve their entrepreneurial contribution to the broader society. The study will be used as an important tool to inform policymakers with regard to the role of foreign academics incapacitating South African universities entrepreneurial abilities.

Problem Statement: South Africa is seated at the lowest level of entrepreneurship education among all African countries with only $40 \%$ of the population having a mindset that building a business is a prudent idea (Ramjugernath, 2015). The issue of lower rate in entrepreneurial education is further confirmed by an economist Duncan (2012) as quoted by (Amadi-Echendu, Phillips, Chodokufa and Visser, 2016:1) where they reiterated that Total Early Stage Entrepreneurial Activity (TEA) have notably decreased by 34\% " (from $10.6 \%$ in 2013 to $7 \%$ in 2014)". This problem is mainly driven by the belief that entrepreneurship is not a 'decent' trade despite vast research in Africa which show that people who build successful businesses and create employment are highly regarded in society (Blecher, 2015). With the above impression in mind, it is argued that since universities are the force of social transformation should spearhead this notion of entrepreneurial education (Radipere 2012). Despite massive unemployment rate in South Africa currently sitting at 26.6\% (Stats SA, 2016), South Africa's post-school education system remains largely preoccupied with producing job seeker graduates (Baijnath, 2015). Baijnath (2015) added that levels of entrepreneurial activity are dropping and the education sector is partly to blame for this. Motsoeneng (2015) mentioned that failure by universities to empower graduates with entrepreneurial education is exacerbated by the fact that lecturers themselves have never been personally exposed to entrepreneurship or established and operated their own small businesses. Therefore, with such a situation where university academics have no knowledge of entrepreneurial education means that they produce graduates with no entrepreneurial knowledge leaving the country with dire need of entrepreneurship educators.

Motsoeneng (2015) emphasised the need to establish entrepreneurship teams within higher education and training facilities in order to promote and succeed in entrepreneurship education. Having highlighted the challenges faced by South Africa above, South African universities are experiencing academic entrepreneurship shortages. This problem has led to little to the non-existence of entrepreneurial universities. Therefore, to address this challenge, South African universities are forced to focus on recruiting foreign academic professionals to try and fasten the promotion of academic entrepreneurship. This premise is highlighted by many authors such as (Jaffe, Lerner, Stern and Thursby 2007; Okoyll and Liefner 2008) (Grundling and Steynberg, 2008). In addition, to cushion the problem of entrepreneurial academic shortages, universities are forced to internationalise and engage international academics in order to push forward the 
agenda of entrepreneurial education successfully. Since foreign academic professionals are part and parcel of the entrepreneurial education, their role in the establishment of entrepreneurial universities needs to be established. The limited availability of data on this aspect necessitates a research study to provide insight and improved approaches to enhancing entrepreneurial universities in South Africa.

Aims and Objectives: The overall aim of the study is to examine the role and impact of foreign academic professionals in the establishment of entrepreneurial universities in South Africa. This issue has prompted the embankment on this research to determine the extent of the role of foreign academic professionals in the development of entrepreneurial universities.

Objectives: To examine the role and impact of foreign academic professionals in the establishment of entrepreneurial universities; To identify and explain various factors affecting the establishment of entrepreneurial universities; To propose an Entrepreneurial Education Model that can be used by South African universities.

\section{Literature Review}

Entrepreneurship and Entrepreneurial University Definition: Rorwana and Tengeh (2015), define entrepreneurship as "the ability and inclination to organize, develop and manage a business in an attempt to make a profit while considering the associated risks. Meyer, 2003 cited in Rorwana and Tengeh (2015) brings the academic angle by defining an academic entrepreneur as an individual who turns knowledge created by institutions of higher learning into "innovation, forms new firms, and creates marketable products and services." Many authors have come up with more than one hundred definitions of the Entrepreneurship concept currently in use (Organisation for Economic Co-operation and Development (OECD) Guiding Framework for Entrepreneurial Universities 2012). An entrepreneurial university is an institution that creates an environment, within which the development of entrepreneurial mindsets and behaviours are embedded, encouraged, supported, incentivised and rewarded (Hannon 2013). Gibb (2014) defines the entrepreneurial university as "those universities providing opportunities, practices, cultures and environments conducive to actively encouraging and embracing student and graduate entrepreneurship. They are places where entrepreneurship is part of the fabric of the institution".

On the same vein, Guerrero and Urbano (2012) refer to an entrepreneurial university as a place where knowledge-based entrepreneurship has emerged as a driving force for economic growth, employment creation and competitiveness in global markets. Considering high unemployment rate in South Africa currently at $27.2 \%$ (Stats SA, 2018), it cannot be over-emphasised that the general perception in South Africa is that entrepreneurship and small business development are the gateways to the alleviation of high unemployment in the country (Amadi-Echendu et al., 2016). With this notion in mind, universities as representatives of social change are expected to lead the entrepreneurial education initiative (Radipere 2012). South African higher education is going through extensive restructuring in order to meet national and global knowledge as well as human capital development (Radipere, 2012). Entrepreneurship education has been inarguably accepted as the main driver in the contribution to economic development and as such, universities as agents of social and economic innovation are expected to do a lot in the success of this initiative. In other words, universities are expected to transform from traditional universities to entrepreneurial universities. Rorwana and Tengeh (2015) also argue that universities are seen as the main contributors to knowledge, innovation and technological advancements. This argument reiterates the need to establish and sustain entrepreneurial universities in South Africa.

International Entrepreneurial University Trends: Entrepreneurship is a phenomenon that has spread and is practised all over the world. In as much as entrepreneurship is needed more in the developing economies, and are still struggling to effect it to young people, developed countries have moved a great deal in effecting this phenomenon. European Commission has even gone to the extent of suggesting that entrepreneurship education is included in the curriculum from primary school (Remeikiene, Startiene and Dumciuviene 2013). Entrepreneurship education has proved to be successful in the developed world to the extent that United Kingdom (UK) has established an Entrepreneurial University Leaders Programme (EULP) which explores the 
changing roles of universities and the benefits of entrepreneurship and innovation to society (Coyle, Gibb and Haskins 2013). The entrepreneurial universities involved in this programme are shown in table 1 below:

Table 1: Entrepreneurial Universities

\begin{tabular}{|c|c|c|}
\hline & UNIVERSITY & INITIATIVE \\
\hline 1 & $\begin{array}{l}\text { University } \\
\text { Oxford }\end{array}$ & $\begin{array}{l}\text { Vision and values in student enterprise } \\
\text { Innovation with impact } \\
\text { Interdisciplinary research and teaching on global } 21^{\text {st }} \text {-century issues }\end{array}$ \\
\hline 2 & $\begin{array}{l}\text { Anglia Ruskin } \\
\text { University }\end{array}$ & $\begin{array}{l}\text { Encouraging staff and students to be part of diverse enterprise activities in the } \\
\text { university in pursuit of innovation } \\
\text { Introduction of the cross-university group to encourage diverse staff to work } \\
\text { together applying entrepreneurial mindset that is already in existence so as to } \\
\text { grow and develop new ventures. }\end{array}$ \\
\hline 3 & $\begin{array}{l}\text { Aberystwyth } \\
\text { University }\end{array}$ & Internationalisation and collaboration for the diverse benefit. \\
\hline 4 & $\begin{array}{l}\text { University of } \\
\text { Wales Newport }\end{array}$ & $\begin{array}{l}\text { Support from the top for an entrepreneurial university } \\
\text { Support for a graduate start-up business and curriculum development }\end{array}$ \\
\hline 5 & $\begin{array}{l}\text { Teesside } \\
\text { University }\end{array}$ & $\begin{array}{l}\text { "Developing enterprising staff with the capability to deliver innovation in teaching, } \\
\text { research and business collaboration" } \\
\text { Develop a cross-disciplinary team project with business- collaboration. }\end{array}$ \\
\hline 6 & $\begin{array}{l}\text { University } \\
\text { Brighton }\end{array}$ & $\begin{array}{l}\text { Knowledge exchange is determined by local need and driven by "co-creating } \\
\text { innovative responses with partners." }\end{array}$ \\
\hline 7 & $\begin{array}{l}\text { University } \\
\text { Dundee }\end{array}$ & $\begin{array}{l}\text { Cross-disciplinary } \\
\text { Partnership }\end{array}$ \\
\hline 8 & $\begin{array}{l}\text { The University of } \\
\text { the West of } \\
\text { England }\end{array}$ & Strong links with business and industry \\
\hline 9 & $\begin{array}{l}\text { The University of } \\
\text { Manchester }\end{array}$ & $\begin{array}{l}\text { Partnership with national departments } \\
\text { Harnessing resources from different stakeholders. }\end{array}$ \\
\hline 10 & $\begin{array}{l}\text { Coventry } \\
\text { University }\end{array}$ & $\begin{array}{l}\text { Development of student enterprise and entrepreneurship } \\
\text { Support bottom-up initiatives for changes in curriculum design. }\end{array}$ \\
\hline 11 & $\begin{array}{l}\text { University } \\
\text { Chester }\end{array}$ & $\begin{array}{l}\text { Stimulating a broad approach to stakeholder engagement in enterprise } \\
\text { Embed enterprise in the university's teaching and learning strategy } \\
\text { Work with different teams and stakeholders within the university interested in } \\
\text { creativity and enterprise so that every student got a chance to exit university with } \\
\text { a module which specifically focuses on the entrepreneurial activity. }\end{array}$ \\
\hline 12 & $\begin{array}{l}\text { University } \\
\text { Copenhagen }\end{array}$ & $\begin{array}{l}\text { Collaborative entrepreneurship between three universities } \\
\text { Produce innovation with societal impact } \\
\text { Establishment of entrepreneurial programs. }\end{array}$ \\
\hline
\end{tabular}
Source: Adapted from (Coyle et al., 2013).

The Need for Entrepreneurial Universities: Jameson and O'Donnell (2015) state that the establishment of an entrepreneurial university represents a chance for transformation and innovation in society, with the ability to respond to the needs of stakeholders and society as a whole. They add that an entrepreneurial 
university has the ability to empower staff, students, stakeholders and the whole community enabling them to effect change in their environment through university's engagement in different activities. According to Baijnath (2015), South African universities are focused on producing graduates who will seek employment instead of employment creators. The goal of the entrepreneurial university, therefore, is not only to generate technology and knowledge about businesses but lead in enforcing 'entrepreneurial thinking' as well as actions among students. Baijnath (2015) argued that entrepreneurship and innovation are key drivers in promoting growth and economic inclusion especially in developing economies like South Africa.

Historical Background of South African Education: High unemployment levels in South African are partly due to constraints inherited from the apartheid era, such as the inequities in access to quality training for certain population groups (Foko 2015). The legacy has resulted in tremendous inequalities in all aspects of education which include resources, infrastructure, teacher quality and post-school endeavours (Chisholm 2012). One of the main legacies of apartheid was poor education, unequal-schooled and poorly trained teachers. This has led to shortages of teachers in crucial subjects and teachers who are not trained to teach these subjects are teaching them thereby making it very difficult to reverse the apartheid legacies. After 1994, the government has effected many changes in education to try and accommodate everyone and reverse the legacies of apartheid but the apartheid repercussions linger on (Chisholm 2012).

Entrepreneurial Universities in South Africa: Radipere (2012) notes that entrepreneurship and small business management education has grown over the years in South African universities but the content does not seem to achieve the desired goal of producing employers, instead most of the entrepreneurship students are seeking jobs. Amadi-Echendu et al. (2016) highlighted that instead of an increase in entrepreneurship activities in the country there had been decreases. They carried out a study in which they explored the potential of the University of South Africa in becoming an entrepreneurial university. Considering the information above, it can be concluded that South Africa is still in its infancy in establishing and sustaining entrepreneurial universities, yet the country is in dire need of entrepreneurial universities to address economic challenges facing the country.

The Role of Foreign Academics in the Establishment of Entrepreneurial Universities: Looking at the educational history of southern Africa, the quality of most graduates still has a negative effect on current students. The negative effects of apartheid are felt across all sectors of the economy (Chisholm 2012), yet the country is desperately in need of entrepreneurial experts to drive and grow the economy, expected to be the driving force behind the production of entrepreneurs (Jameson and O'Donnell 2015). Garbuio; Dong; Lin; Tschang; and Lovallo $(2018)$ reiterate and recommend that academics should 'creatively cross-fertilize ideas, practices, and knowledge', as well as seek assistance and work with experts in entrepreneurship around the world for successful achievement of entrepreneurship training among youths. Due to the legacies of apartheid in South African education, higher education has serious shortages of entrepreneurial experts who can drive entrepreneurial forward (Motsoeneng 2015). Therefore, to cushion this shortage, South Africa is forced to look beyond its borders for experts. Ramjugernath (2015) reiterated that internationalisation is key to entrepreneurship plan whereby universities have to attract foreign and entrepreneurial staff to demonstrate internationalisation teaching. On the vein, Ramjugernath (2015) added that South Africa cannot push the agenda of innovation and entrepreneurship alone without international experts. Ramjugernath (2015) emphasised the need for South Africa to use partnership and resources globally in order to drive the entrepreneurship agenda forward. The aim of the empirical study - to research the role played by foreign academic professionals in the establishment of entrepreneurial university in South Africa was encouraged by the fact that the analysed literature lacks research on comparative analysis of the role and extent of the role played by international entrepreneurial academic experts in the establishment and sustainability of entrepreneurial universities in South Africa.

\section{Research Methodology}

Considering the huge benefits posed by mixed methods outlined as outlined by Anguera, Camerino, Castañer, Sánchez-Algarra and Onwuegbuzie AJ (2017), this approach was employed in this study. The literature review was used as the main source of information from which data collection instrument was formulated. The questionnaire made up of 5 -point Likert scale of closed-ended and open-ended questions was formed 
and was used for the collection of empirical data for this study. Summary of key questions are highlighted in Table 2 below:

Table 2: Key Question Summary

\begin{tabular}{|c|c|}
\hline Research Area & Question \\
\hline Entrepreneurial education & $\begin{array}{l}\text { Every university must internationalise in order to succeed in entrepreneurial } \\
\text { education. }\end{array}$ \\
\hline $\begin{array}{l}\text { Foreign } \\
\text { professionals }\end{array}$ & $\begin{array}{l}\text { Foreign academic professionals have the required skills for the establishment } \\
\text { of entrepreneurial universities. }\end{array}$ \\
\hline Entrepreneurial institutes & Establish an entrepreneurial institute affiliated to the established university. \\
\hline Entrepreneurship expertise & Foreign academics bring diverse expertise in entrepreneurship studies. \\
\hline Entrepreneurship mindset & $\begin{array}{l}\text { The presence of foreign academics has enhanced entrepreneurship mindset } \\
\text { among staff and students. }\end{array}$ \\
\hline $\begin{array}{l}\text { Establishment of } \\
\text { entrepreneurial universities }\end{array}$ & Establishment of entrepreneurial universities is the way to go in South Africa. \\
\hline
\end{tabular}

Target Population: The study was based on universities in South Africa operating under the Department of Higher education and training (government funded). The target population for this study was therefore based on 26 universities in South Africa (Business Tech 2015). Data for the study was collected by way of selfadministered questionnaires to heads of departments of the universities.

\section{Preliminary Findings}

This section is based on the literature review as well as preliminary findings and they indicate the following:

Findings from Secondary Data

Table 3: Secondary Data Findings

\begin{tabular}{|c|c|c|c|}
\hline Research Area & & Literature review & Noticeable current Gaps \\
\hline $\begin{array}{l}\text { Educational } \\
\text { expertise } \\
\text { knowledge } \\
\text { entrepreneurial } \\
\text { university }\end{array}$ & $\begin{array}{l}\text { and } \\
\text { of }\end{array}$ & $\begin{array}{l}\text { In as much as the universities are willing to } \\
\text { succeed in becoming entrepreneurial, they are } \\
\text { faced with lack of academics in the field of } \\
\text { entrepreneurship. Failure by universities to } \\
\text { empower graduates with entrepreneurial } \\
\text { education is exacerbated by the fact that } \\
\text { lecturers themselves have never been } \\
\text { personally exposed to entrepreneurship or }\end{array}$ & $\begin{array}{l}\text { According to the findings from } \\
\text { literature there are not much- } \\
\text { needed skills among academics } \\
\text { with regard to the establishment } \\
\text { of entrepreneurial universities in } \\
\text { South Africa. Lack of knowledge } \\
\text { pertaining to entrepreneurial } \\
\text { university functions. }\end{array}$ \\
\hline
\end{tabular}
established and operated their own small businesses. In addition, the government through the National Planning commission has instigated "policy and structural developments to promote entrepreneurship, build capacity and foster entrepreneurial thinking starting at the educational level." South Africa is seated at the lowest level of entrepreneurship education among all African countries with only $40 \%$ of the population having a mindset that building a business is a prudent idea. The issue of lower rate in entrepreneurial education is further confirmed by an economist Duncan (2012) where it is reiterated that Total Early Stage Entrepreneurial Activity (TEA) have notably decreased by 34\% " (from 10.6\% in 2013 to 7\% in 2014)". (Motsoeng, 2015:1, Baijnath, 2015, Ramjugernath, 2015). 
Challenges on the Many authors indicated that lack of establishment of entrepreneurial university knowledge is the entrepreneurial Universities major obstacle to the establishment of Entrepreneurial universities in South Africa. They added that there is a lack of entrepreneurial culture among South Africans in general. It was also revealed that South African higher education institutions are grappling to comply with the focal need of the South African economy - the enhancement of academic entrepreneurship (Nicolaides, 2011, Atkinson, 2014, Grundling and Steynberg, 2014)

Perception of the role played by foreign academics

\section{Implementation of}

the

entrepreneurship drive
A number of researchers found out that the legacies of apartheid in the south African education have led to massive shortages of entrepreneurial experts who can drive entrepreneurial activities forward. Therefore, to alleviate this shortage, South Africa is forced to look beyond its borders for experts. They reiterated that internationalisation is key to entrepreneurship plan whereby universities have to attract foreign and entrepreneurial staff to demonstrate internationalisation teaching. They added that South Africa cannot push the agenda of innovation and entrepreneurship alone without international experts. They also emphasised the need for South Africa to use partnership and resources globally in order to drive the entrepreneurship agenda forward. Moreover, it was found that there is a generally negative perception towards foreign nationals in South Africa despite them possessing great entrepreneurial skills. (Motsoeneng 2015, Ramjugernath 2015, Jameson and O'Donnell 2015, Vivence and Kobus, 2010).

A considerable amount of research previously done in other parts of the world including South Africa, revealed that higher education studies should develop entrepreneurial preparedness, thus programs designed for any faculty should be supplemented with the subjects enabling to form entrepreneurial knowledge and skills. South Africa has been found to have the lowest level of entrepreneurial education as highlighted by the Total early-stage Entrepreneurial Activity (TIA) which has decreased from 10.6\% in 2013 t0 7\% in 2014. Due to the successful results of entrepreneurship education in the developed
Based on literature review findings, there is generally low level of entrepreneurial education and training in the country of South Africa. No effort by South African universities to develop cross-functional thinkers who are innovative and possess entrepreneurial skills. Unavailability of entrepreneurship drive by local universities through programme designs specialised post-graduate programmes in entrepreneurship. There is a need for the South African education system to transform so as to make entrepreneurship one of the most crucial subjects.

There is evidence that non-South African citizens possess much needed entrepreneurial skills for South African economy upliftment however, the literature reviewed indicated that there is a generally negative perception towards them and their contribution from all sectors including education. Therefore, in many cases, whatever, the contribution made by them is likely not to be taken seriously or rather been not implement at all.

Higher education needs to redefine its role in the south African economy. Their main duty should be to instil a greater entrepreneurial mentality among students as well as orientating Universities to become entrepreneurial universities. Thus will provide the required entrepreneurial knowledge and skills. 
world United Kingdom (UK) has established an Entrepreneurial University Leaders Programme (EULP) which explores the changing roles of universities and the benefits of entrepreneurship and innovation to society. (Remeikiene, Startiene and Dumciuviene 2013, Coyle, Gibb and Haskins 2013, Amadi-Echendu et.al 2016 and Beijnath 2015).

The concept of the entrepreneurial university
There is an agreement among researchers that entrepreneurial universities have got a high potential of cushioning economies of unemployment and poverty in today's highly turbulent and unpredictable markets. Hence, the entrepreneurial university has the ability to empower staff, students, stakeholders and a community as a whole through university's engagement in different activities (Sperrer, Miiller and Soos 2016, Jameson and O'Donnell 2015).
Based on these readings entrepreneurial universities can be important tools that can be used to tackle turbulent environments and complex challenges confronting societies and communities around the world. As a result, South Africa should also be beginning to transform its universities to be entrepreneurial universities.

Entrepreneurship Education: the Previous study by Denanyoh, Adjei and Nyemekye (2015), indicate a link between education and entrepreneurship since the education offered by a university mostly influences the career selection of students, universities can be seen as potential sources of future entrepreneurs. Today, most universities have spent significant amounts of money to design a viable entrepreneurship education for their students. In addition, the country educational system currently does not support entrepreneurial development as it focuses on training students to be employed in government agencies or multinational organizations. There are ten (10) Polytechnics in Ghana and only one of them (Kumasi Polytechnic) have established an Entrepreneurship Training Institute to train students in that area of study. Entrepreneurship academies are in non-existence in Ghana and the polytechnics which are the most practically oriented higher institution of learning in the country that can effectively combine technical and business management skills and training and turnout entrepreneurs. It is clear that the existing level of entrepreneurship education in Ghana is quite insufficient to foster entrepreneurship and there is a need to focus on entrepreneurship education. Obviously, understanding perceptions of students at higher education level is a necessary step in this process. A study by Turker and Selcuk (2009) showed that education plays a key role in the development of students' entrepreneurial intentions in Turkey. In an earlier study, Kolvereid and Moen (1997) also indicated a link between education in entrepreneurship and entrepreneurial behaviour. It is clear that an effective education on entrepreneurship can be a factor to push people towards an entrepreneurial career (Henderson and Robertson, 2000).

Perceptions on the Role Played by Foreign Academic Professionals in the Establishment of Entrepreneurial Universities: Guerrero and Urbano (2012) found that an academic entrepreneur is considered a role model who can impact positively in the entrepreneurial university community. They went on to point out that the main factors behind the entrepreneurial universities in other countries like Spain are the entrepreneurial attitudes of academics, researchers, staff and students. Therefore, a sufficient fusion of the university leadership and the positive attitudes towards entrepreneurship of the university community make significant changes possible within the university.

Preliminary Findings: The previous sections presented the literature review used to formulate variables tested for this study. Therefore, the findings from the pilot study conducted are presented in the following section. These findings were derived from the targeted respondents to test the proposed methodology employed in this study. These results are purely based on the pilot study findings and are presented as such. 
Table 4: Preliminary Findings

\begin{tabular}{|c|c|c|c|c|c|c|c|}
\hline Statement & $\begin{array}{l}\text { Strongly } \\
\text { Disagree }\end{array}$ & Disagree & & Neutral & & Agree & Strongly Agree \\
\hline $\begin{array}{l}\text { Every university must } \\
\text { internationalise in } \\
\text { order to succeed in } \\
\text { entrepreneurship } \\
\text { education. }\end{array}$ & $\begin{array}{l}\text { Internationalise } \\
=1(10 . \%)\end{array}$ & $\begin{array}{l}\text { Internationalis } \\
=0\end{array}$ & & $\begin{array}{l}\text { Internationalis } \\
=2(22 . \%)\end{array}$ & & $\begin{array}{l}\text { Internationalise } \\
=3(33 . \%)\end{array}$ & $\begin{array}{l}\text { Internationalise } \\
=4(35 \%)\end{array}$ \\
\hline $\begin{array}{l}\text { Foreign academics } \\
\text { have the required } \\
\text { skills for the } \\
\text { establishment of } \\
\text { entrepreneurial } \\
\text { universities. }\end{array}$ & Skills $=0$ & Skill $=0$ & & Skills $=0$ & & Skills $=1(11 \%)$ & Skills $=9(89 \%)$ \\
\hline $\begin{array}{l}\text { Establish an } \\
\text { entrepreneurial } \\
\text { institute affiliated to } \\
\text { the established } \\
\text { university. }\end{array}$ & Institute $=0$ & $\begin{array}{l}\text { Institute } \\
1(11 \%)\end{array}$ & $=$ & $\begin{array}{l}\text { Institute } \\
1(11 \%)\end{array}$ & $=$ & $\begin{array}{l}\text { Institute } \\
=2(22 \%)\end{array}$ & $\begin{array}{l}\text { Institute } \\
6(56 \%)\end{array}$ \\
\hline $\begin{array}{l}\text { Foreign academics } \\
\text { bring diverse expertise } \\
\text { in entrepreneurship } \\
\text { studies. }\end{array}$ & Expertise $=0$ & $\begin{array}{l}\text { Expertise } \\
1(11 \%)\end{array}$ & $=$ & $\begin{array}{l}\text { Expertise } \\
1(11 \%)\end{array}$ & $=$ & Expertise $=78 \%$ & Expertise $=0$ \\
\hline $\begin{array}{l}\text { The presence of } \\
\text { foreign academics has } \\
\text { enhanced } \\
\text { entrepreneurship } \\
\text { mind set among staff } \\
\text { and students. }\end{array}$ & Enhanced $=0$ & $\begin{array}{l}\text { Enhanced } \\
1(11 \%)\end{array}$ & $=$ & $\begin{array}{l}\text { Enhanced } \\
3(33 \%)\end{array}$ & $=$ & $\begin{array}{l}\text { Enhanced } \\
1(11 \%)\end{array}$ & $\begin{array}{l}\text { Enhanced } \\
5(45 \%)\end{array}$ \\
\hline $\begin{array}{l}\text { Establishment of } \\
\text { entrepreneurial } \\
\text { universities is the way } \\
\text { to go in South Africa. }\end{array}$ & Way $=0$ & Way $=0$ & & Way $=0$ & & Way $=3(33 \%)$ & Way = 7(67\%) \\
\hline
\end{tabular}

A Likert-type scale was used to address some of the variables in this study and six of these were addressed in table 4 above. Majority of the respondents are in agreement to all of the six statements which emphasise that: there is a need for all universities to internationalise; foreign academics have got the required skills; universities need to establish entrepreneurial institutes; foreign academics bring diverse expertise; the presence of foreign academics has enhanced entrepreneurship mindset and that the establishment of entrepreneurial universities is the way to go in South Africa if the country is to succeed in economic development and poverty alleviation through producing more job creators than job seekers. This notion is in agreement with (Nourizadeh, 2017)'s findings in which the study emphasises that academic entrepreneurial approach as the way to go in adapting universities to the needs and goals of nations as well as solving government, community and business problems.

\section{Figure 1: How Many International Academics Are in Your Department/Division?}

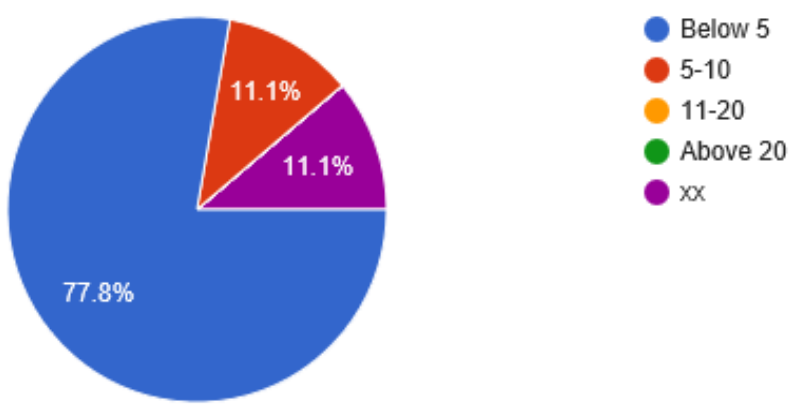


Many authors such as (Coyle et al., 2013, Ramjugernath 2015 and Motsoeng 2015) reiterated the need for universities to internationalise through the engagement of international academics if the goal of entrepreneurial university establishment is to be achieved. In figure 1 above, most of the respondents $(77.8 \%)$ indicated that there are less than five (5) international academics in their departments, $11 \%$ of the respondents indicated that they had below ten (10) while $11 \%$ have no single international academic in their departments.

Figure 2: Lack of Entrepreneurial Drive

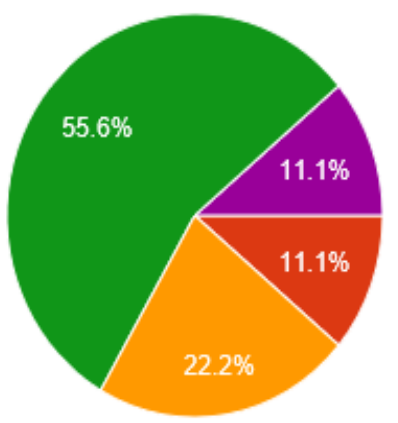

\author{
Strongly disagree \\ Disagree \\ Neutral \\ Agree \\ Strongly agree
}

It has been found that there is a lack of entrepreneurial spirit and knowledge as well as lack of business managerial skills and inadequate education and training among some South African communities (Henning and Akoob, 2017). Sperrer, Müller, and Soos (2016) found that there is a lack of entrepreneurial drive among universities. Figure 2 share the same sentiments as it indicates that more than two thirds (66.7\%) $(55.6 \%$ $+11.1 \%$ ) of respondents agree that South African Universities widely lack the entrepreneurial drive.

Qualitative Preliminary Findings: This section presents the findings obtained from the qualitative data and are shown in the table below presents the responses.

Table 5: How is Entrepreneurship Education Accommodated in Your University?

Response 1: We have a department fully dedicated to entrepreneurial education. This department offers undergraduate up to $\mathrm{PhD}$ level

Response 2: It is part of the curriculum

Response 3: modules are taught

Response 4: It's not significantly highlighted

Response 5: Very poor

Response 6: not much

Response 7: As General Education Module and in the major subject BPRM

Response 8: I believe there is really a strong drive for entrepreneurship from this current VC's office

\title{
Expectations from International Academics
}

Response 1: I expect complex experience and knowledge

Response 2: To bring another perspective

Response 3: to change the employment status of youth

Response 4: to bring innovative ways in which the curriculum can be modified and incorporate entrepreneurship

Response 5: their skills contribution

Response 6: must participate fully

Response 7: Their diverse input in how entrepreneurship is successful in their country

Response 8: I expect African internationals to collaborate with local Africans to establish a hub where Africans can export African products that

Response 9: Are of great international standards at the same time raise our African generational wealth, by making sure we open doors for our youth. 
Considering High Rate of Unemployment in the Country, Entrepreneurship is seen as an Effective Tool in Addressing Unemployment, How is Your University Working towards Embracing the Idea of Entrepreneurship Education?

Response 1: The University has a division with incubators for young entrepreneurs

Response 2: try to align industry demand with the curriculum

Response 3: the new curriculum is embracing entrepreneurship

Response 4: there has been the establishment of such offices to promote leaders and owners of business but it is still new.

Response 5: not started yet.

Response 6: not much is done

Response 7: It is a module that is compulsory for all students in the faculty and in some subjects it has to be embedded in the curriculum

What is the Problems Encountered in the Establishment of Entrepreneurial Universities in South Africa?

Response 1: Experienced staff

Response 2: Not sure

Response 3: I think universities management philosophy, standard curriculum, resources

Response 4: poor vision

Response 5: lack of drivers and expertise to establish centres to promote entrepreneurial universities

Response 6: scares resources

Response 7: staff members with a business mentality

Response 8: Lack of desire and effort from academics

Response 9: not enough of a relationship in terms of collaboration between people who work in the industry and what happens there and the academic curriculum.

Table 5 above generally highlights that entrepreneurship education is covered at a small scale taught once-off as a module and in only one department. In addition, the respondents expect the international academics to bring and share their expertise with local academics for the successful achievement of economic employment growth through the production of entrepreneurially vested graduates. The respondents also indicate that entrepreneurship is not fully embedded in all faculties of the university. All in all, they highlighted a vast number of problems hindering universities from becoming entrepreneurial.

Some of Which Include: lack of experienced staff, university vision, staff members' entrepreneurship mentality and lack of university collaboration with experts in the field.

Limitation: There is a need to acknowledge before conclusion and recommendations are postulated. The findings are only based on the literature and preliminary results for now as the empirical study is still under construction. On this account, the findings presented here cannot be generalised for the full sample of all South African universities perspective.

\section{Conclusion and Recommendations}

This study found that foreign academics have the required skills to drive the establishment of entrepreneurial universities in South Africa. In addition, the study highlighted the need for an establishment of an entrepreneurial institute affiliated to the traditional university. It also established that foreign academics have got diverse expertise needed for the development of entrepreneurial universities and have enhanced entrepreneurship mindset among students and staff members. Moreover, the study indicated that most respondents agree that universities should internationalise in order to succeed in entrepreneurial education. All in all, the study concluded that the establishment of entrepreneurial universities is the way to go in South Africa. 
Recommendations: Since literature has indicated that there are not enough entrepreneurial skills, therefore, this study recommends that the hiring of foreign academics with the much needed entrepreneurial expertise should be taken into consideration by the South African authorities. Due to the lack of knowledge with regard to the entrepreneurial skills necessary to drive/ transform the universities into becoming entrepreneurial universities, South African government should rework education and development policy in order to allow the adoption of much required and highly specialised international people to come to South Africa and teach and transfer knowledge to the local universities and communities. According to the study, if a tertiary institution provides adequate knowledge and inspiration for entrepreneurship, the possibility of choosing an entrepreneurial career might increase among students after graduation. It is demonstrated that this result confirms the key role of education in the development of entrepreneurial intention. Therefore, it might be stated that entrepreneurship can be enhanced as a result of a learning process. Literature also provides validation that South African universities need to be transformed into entrepreneurial universities. All in all, internationalisation of universities and establishment of entrepreneurial universities is the way to go to South Africa if the country is to succeed in employment creation and poverty reduction.

Implications: The implications of this research consist of two main aspects namely: Implications of the establishment of entrepreneurial universities theory and Implications of entrepreneurial universities practice.

Implications of the Establishment of Entrepreneurial Universities Theory: The implications of the theory will provide a theoretical knowledge framework by highlighting the aspects to be understood and known by the authorities with regard to the establishment of entrepreneurial universities in South Africa. In addition, the theory will also contribute towards introducing and imparting entrepreneurial skills among students earlier in their education career.

Implications of Entrepreneurial Universities Practice: The practical implication of this study will help the policymakers and will be used as a practical guide tool in formulating the education policies which enhance the development of entrepreneurial universities in the country. Moreover, this study will assist higher education authorities in providing an enabling environment for universities to transform into entrepreneurial.

\section{References}

Amadi-Echendu, A. P., Phillips, M., Chodokufa, K. \& Visser, T. (2016). Entrepreneurial Education in a Tertiary Context: A Perspective of the University of South Africa. International Review of Research in Open and Distributed Learning, 17, (4).

Anguera, M. T., Camerino, O., Castañer, M., Sánchez-Algarra, P. \& Onwuegbuzie, A. J. (2017). The Specificity of Observational Studies in Physical Activity and Sports Sciences: Moving Forward in Mixed Methods Research and Proposals for Achieving Quantitative and Qualitative Symmetry. Front. Psychol.

Baijnath, N. (2015). The urgent need to enable and sustain entrepreneurship. University World News, 13.

Blecher, T. (2015). Calls for entrepreneurship education in universities. University World News, 27 March: 3.

Business Tech. (2015). Here are South Africa's 26 universities, Business tech.

Chisholm, L. (2012). Apartheid education legacies and new directions in post-apartheid South Africa. Storia delle donne, 8, 81-103.

Coventry University. (2018). Academic partner institutions.

Coyle, P., Gibb, A. \& Haskins, G. (2013). The entrepreneurial university: From concept to action. The Entrepreneurial University Leaders Programme (EULP). National Centre for Entrepreneurship in Education (NCEE), 4, 1-59.

Denanyoh, R., Adjei, K. \& Nyemekye, G. E. (2015). Factors That Impact on Entrepreneurial Intention of Tertiary Students in Ghana. International Journal of Business and Social Research, 05(03), 19-29.

Eke, P. O., Okoye, L. U., Evbuomwan, G. O. (2018). A Dynamic Analysis of the Nexus between Entrepreneurship, Human Capital Development and Financial Deepening: Evidence from Selected African Economies. Journal of Applied Economic Sciences, Volume XIII, 5(59). 
Fernández-Nogueira, D., Arruti, A., Markuerkiaga, L., Sáenz, N. (2018). The entrepreneurial university: a selection of good practices. Journal of Entrepreneurship Education, 21, 1-17.

Foko, B. (2015). Closing South Africa's High-Skilled Worker Gap: Higher Education Challenges and Pathways. African Economic Brief, 6(7), 1-20.

Garbuio, M., Dong, A., Lin, N., Tschang, T. \& Lovallo, D. (2018). Demystifying the genius of entrepreneurship: How design cognition can help create the next generation of entrepreneurs. (2018). Academy of Management Learning and Education, 17, (1), 41-61.

Gibb, A. (2014). Towards the entrepreneurial University. Entrepreneurship education as a lever for change, A National Council for Graduate Entrepreneurship (NCGE), 1-14.

Guerrero, M. \& Urbano, D. (2012). The development of an entrepreneurial university. The Journal of Technology Transfer, Springer, 37, 43-74.

Grundling, J. \& Steynberg, L. (2008). Academic Entrepreneurship: Challenges facing South Africa. The 16th Annual High Technology Small Firms Conference. University of Twente, Enschede, The Netherlands, 22-23 May 2008. Enschede, The Netherlands: University of Twente, 1-16.

Hannon, P. D. (2013). Why is the Entrepreneurial University Important? Journal of Innovation Management, $1(2), 10-17$

Henderson, R. \& Robertson, M. (2000). Who wants to be an entrepreneur? Young adult attitudes towards entrepreneurship as a career.

Henning, S. \& Akoob, K. (2017). Motivational factors affecting informal women entrepreneurs in North-West Province, Southern African Journal of Entrepreneurship and Small Business Management, 9(1), 91.

Fokon, S. L. (2011). Research methods: A modular approach. 2nd ed. Wadsworth: Cengage Learning.

Jaffe, A., Lerner, J., Stern, S. \& Thursby, M. (2007). Academic Science and Entrepreneurship: Dual Engines of Growth. Journal of Economic Behavior and Organization, 63(4).

Jameson, J. \& O'Donnell, P. (2015). The Entrepreneurial University: A Unifying Theme for TU4Dublin. Stream 1: Enterprise and Engagement, 69-81.

Kolvereid, L. \& Moen, Ø. (1997). Entrepreneurship Among Business Graduates: Does a Major in Entrepreneurship Make a Difference? Journal of European Industrial Training, 21, 154-160.

Kroll, H. \& Liefner, I. (2008). Spin-off enterprises as a means of technology commercialisation in a transforming economy-Evidence from three universities in China. Technovation, 28, 298-313.

Motsoeneng, M. (2015). Calls for entrepreneurship education in universities. University World News, 27.

Nourizadeh, M. (2017). Assessing organizational entrepreneurship in Alzahra University. Quantitative Models and Techniques in Management, 1(1), 1-9.

OECD. (2012). A Guiding Framework for Entrepreneurial Universities.

Radipere, S. (2012). South African university entrepreneurship education. African Journal of Business Management, 6(44), 11015-11022.

Ramjugemath, D. (2015). Six key elements of an entrepreneurial university. University World News, 7 November: 1.

Remeikiene, R., Startiene, G. \& Dumciuviene, D. (2013). Explaining Entrepreneurial intention of university students: The role of entrepreneurial education. Management, Knowledge and Learning International Conference. Zadar, Croatia, 19-21 June.

Rorwana, A. \& Tengeh, R. K. (2015). The role of academic entrepreneurs in the process of technology transfer and commercialization: the case of a University of Technology in South Africa. Environmental Economics, 6(4), 25-37.

Sperrer, M., Müller, C. \& Soos, J. (2016). The Concept of the Entrepreneurial University Applied to Universities of Technology in Austria: Already Reality or a Vision of the Future? Technology Innovation Management Review, 6(10), 37-44.

Statistics South Africa. (2016). South Africa Unemployment Rate 2000-2017.

Statistics South Africa. (2018). SA unemployment rate rises to $27.2 \%$ in Q2.

The University of Manchester. (2018). University of Manchester Equity and Diversity Policy.

Turker, D. \& Selcuk, S. S. (2009). Which factors affect entrepreneurial intention of University students? Journal of European Industrial Training, 33(2), 142-159.

University of Oxford. (2017). Annual Staffing Figures 2016/17 reporting year. 